\title{
The Jurisprudence of Legitimacy: Applying the Constitution to U.S. Territories
}

\author{
Robert A. Katz†
}

To what extent does the Constitution "follow the flag" to territories under United States sovereignty?" Though this question has twice occupied the center stage of American law and politics, ${ }^{2}$ federal courts have yet to settle upon a single test for determining which constitutional provisions apply to United States-flag territories. Federal circuit courts currently divide between two competing approaches for making this determination. ${ }^{3}$ Employing these rival standards, they have reached inconsistent results concerning the territorial force of certain constitutional rights, such as the right to trial by jury.

This Comment undertakes to explain the doctrinal disagreement between the two federal circuits whose discord runs the deepest: the D.C. Circuit, which has jurisdiction over American Samoa, and the Ninth Circuit, which hears appeals from the Northern Mariana Islands and Guam. One way to analyze their dispute is to focus on the disorder within the Supreme Court's own territorial jurisprudence. Each of the two approaches employed by the lower courts traces its origin to different Supreme Court opinions.

$\dagger$ A.B. 1987, Harvard University; J.D. Candidate 1992, The University of Chicago. This Comment was awarded a D. Francis Bustin prize for excellence in student scholarship at the law school.

1 The United States' territorial system consists of five island groups that fly the American flag but which are not states-Puerto Rico, the Virgin Islands, Guam, the Northern Mariana Islands, and American Samoa. The United States also has special responsibilities for the Federated States of Micronesia, the Marshall Islands and Palau. This latter category is beyond the scope of this Comment.

${ }^{2}$ See Gary Lawson, Territorial Governments and the Limits of Formalism, $78 \mathrm{Cal} \mathrm{L}$ $\operatorname{Rev} 853,857$ n 14 (1990) (the constitutional status of American territories was a central question just prior to the Civil War, when debate concerned slavery in the territories; and again at the turn of the twentieth century, when debate focused on the possessions acquired in the "imperialist" era).

s The D.C. Circuit has held that all of the Constitution's safeguards of individual rights must apply to the territories of the United States, except those whose implementation proves to be "impractical and anomalous" in a given setting. King $v$ Morton, 520 F2d 1140, 1147 (DC Cir 1975). The Ninth Circuit, on the other hand, holds that only "fundamental" constitutional rights must apply to these territories. See Commonwealth of the Northern Mariana Islands o Atalig, 723 F2d 682, 689-90 (9th Cir 1984). 
Common sense suggests that the Court's failure to speak with one voice has played a major role in the disharmony below.

Another way to analyze the circuit split is to consider the broader moral and political concerns that might have driven the circuits to develop their jurisprudence along such divergent paths. More specifically, one might ask how the lower courts have developed their accounts of territorial jurisprudence so as to reinforce the legitimacy of the United States' authority over its territories. There are many reasons why courts might feel obliged to address such concerns, since America's governance of distant, insular territories has always proved morally problematic. As an initial matter, the United States asserted control over its present holdings without first seeking the consent of the native inhabitants. ${ }^{4}$ Moreover, unlike earlier acquisitions in North America, the offshore islands are not expected to join the Union as states. For this reason, their inhabitants will never "ordain and establish" the federal constitution (and the government it created) in the manner anticipated by the document itself. ${ }^{5}$

This Comment argues that the doctrinal dispute between the two circuits reflects a profound debate over how to justify compelling territorial inhabitants to obey the government of the United States. The lower courts, the Comment will demonstrate, decide how extensively the Constitution "follows the flag" to a particular territory with an eye towards explaining why its residents must follow (i.e., pledge allegiance to) our flag. Analyzing the case law in this manner suggests an unorthodox conclusion: perhaps this circuit split should remain unresolved. The Supreme Court's failure to answer the formal constitutional question serves a larger moralpolitical function. It has enabled lower federal courts to maximize the legitimacy of the United States' authority in each particular territory.

Section I of this Comment presents an overview of the Supreme Court's territorial jurisprudence, focusing on the Court's two rules for analyzing the Constitution's territorial reach. Section II discusses how the D.C. and Ninth Circuits have deepened this doctrinal divergence in their application of the Constitution to

- The United States captured Puerto Rico and Guam as a result of an expansionist war, acquired American Samoa pursuant to a partition agreement with other imperial powers, purchased the Virgin Islands from Denmark, and began administering the Northern Mariana Islands pursuant to an agreement with the United Nations.

${ }^{\circ}$ See US Const, Art IV, $\$ 3$ ("New States may be admitted by the Congress into this Union ...."). 
American Samoa and the Northern Mariana Islands, respectively. Section III explains why the disorder within the Supreme Court's jurisprudence does not account for the circuit split, and presents a framework for appreciating the role of legitimacy in United States territorial governance. Section IV employs a legitimacy-focused approach to explain the apparent split between the two circuits. Section $\mathrm{V}$ argues that this doctrinal division should be left intact. More generally, the Comment indicates when one approach is to be preferred over the other. Lastly, this Comment suggests that the legal and moral dilemmas that underlie territorial governance are beyond the judiciary's capacity to resolve.

\section{The Supreme Court's Territorial Jurisprudence}

\section{A. The Insular Cases Doctrine}

The Supreme Court laid the constitutional groundwork for the modern American territorial system in the so-called Insular Cases. ${ }^{6}$ This series of cases examined the constitutional issues raised by the United States' acquisition of offshore island (i.e., "insular") areas after the Spanish-American War of 1898. The most important of these cases is Downes $v$ Bidwell, ${ }^{7}$ which contained a seminal concurring opinion by Justice Edward Douglas White. According to White, territories acquired by the United States fall into two categories: "incorporated" territories, which are "an integral part of the United States," full members of "the American family,"s and likely candidates for eventual statehood;" and "unincorporated" territories, which are held merely "appurtenant" to the United States, and seen as "foreign . . . in the domestic sense."10

White further argued that the application of the Constitution to a territory depends on its status under this scheme. ${ }^{11}$ Generally speaking, all of the Constitution's provisions automatically apply to territories which have been incorporated into the United

- The leading Insular Cases are Downes v Bidwell, 182 US 244 (1901); Hawaii v Mankichi, 190 US 197 (1903); Dorr v United States, 195 US 138 (1904); and Balzac v Porto Rico, 258 US 298 (1922).

182 US 244 (1901):

- Id at 339, 342 (White concurring).

- See Frederick R. Coudert, The Evolution of the Doctrine of Territorial Incorporation, 26 Colum L Rev 823, 834 (1926) (arguing that Justice White thought incorporation implied a promise of ultimate statehood).

${ }^{10}$ Downes, 182 US at 341-42 (White concurring).

"Id at 293. 
States. ${ }^{12}$ Unincorporated territories, by contrast, need not be shielded by all of the Constitution's provisions, thus permitting the federal government to avoid certain constitutional limitations in governing them. ${ }^{13}$ Twenty-one years after Downes, a unanimous Supreme Court embraced White's doctrine of territorial incorporation, otherwise known as the "Insular Cases doctrine," as the law of the land. ${ }^{14}$

\section{B. The "Fundamental Rights" Test}

Once one accepts the principle enunciated in the Insular Cases-that not all constitutional provisions must apply to unincorporated territories-it becomes necessary to identify those provisions of the Constitution which do in fact apply there. The traditional approach set forth in the Insular Cases holds that only those constitutional provisions that protect the "fundamental" rights of individuals must extend overseas. ${ }^{15}$ Here again Justice White's concurring opinion in Downes provided the initial inspiration. He explained that even though unincorporated territories were to receive less than complete constitutional protection, they still benefit from "inherent, although unexpressed, principles which are the basis of all free government;" "restrictions of so fundamental a nature that they cannot be transgressed. ..."16 These restrictions prohibit the government from disabling personal rights, thereby affirming those constitutional provisions that protect "human liberty."

To identify these "fundamental" provisions, White invited judges to invoke a natural rights philosophy. ${ }^{18}$ The results of this inquiry are categorical-a right either is or is not "fundamental" in the territorial context, and its nature as such will not vary from setting to setting. Thus, once a court characterizes a right as nonfundamental with respect to any one unincorporated territory,

\footnotetext{
${ }^{12}$ See id at 299 (if Puerto Rico had been incorporated into the United States, a special duty on goods imported from that island would have been repugnant to the Uniformity Clause of the Constitution).

${ }^{13}$ See id at 342.

${ }^{14}$ See Balzac, 258 US at 312-13. For a recent affirmation of the doctrine, see United States $v$ Verdugo-Urquidez, 494 US 259, 268-69 (1990).

${ }^{15}$ See Balzac, 258 US at 312-13. See also Dorr, 195 US at 147.

${ }^{16}$ Downes, 182 US at 291 (White concurring) (emphasis added).

17 Id at 292.

${ }^{18}$ Downes, 182 US at 291 (White concurring). See also Gerald L. Neuman, Whose Constitution?, 100 Yale L J 909, 962 (1991) (arguing that White employed natural law methodology to identify which provisions are "fundamental").
} 
it will consider that right to be nonfundamental with respect to all unincorporated territories. ${ }^{19}$

The Insular Cases definition of a "fundamental" right is best illustrated by the actual decisions of various cases. As employed by the Court, this approach only denied unincorporated territories the right to trial by jury, ${ }^{20}$ the right to presentment by grand jury, ${ }^{21}$ and the right to confront witnesses. ${ }^{22}$ According to the Court, these rights were "not fundamental in their nature," cial rights of criminal procedure peculiar to Anglo-Saxon legal systems. ${ }^{24}$ In contrast, dicta in the Insular Cases suggests that the Court viewed most of the personal rights and privileges guaranteed by the Constitution as "fundamental" in the territorial context, ${ }^{25}$ including the guarantees of due process, ${ }^{26}$ and the prohibitions of ex post facto laws and bills of attainder. ${ }^{27}$

\section{Justice Harlan's "Impractical and Anomalous" Test}

The Supreme Court's other standard for measuring the Constitution's territorial extent derives from Justice Harlan's concurrence in Reid $v$ Covert. ${ }^{28}$ Harlan understood the Insular Cases as employing a due-process-like balancing test to determine which constitutional provisions apply overseas. ${ }^{29}$ In the territorial context, this balancing test requires courts to weigh the government's plenary power to rule territories against an individual's right to specific constitutional safeguards of personal liberty. ${ }^{30}$ In order to deny the extension of a right, the government must demonstrate that affording the native population the right would be "impractical and anomalous" in the given setting. ${ }^{31}$ "[T] of the Insular Cases, Harlan asserted, "is [that] there is no rigid

\footnotetext{
19 See, for example, Balzac, 258 US at 304-05 ("It is . . clearly settled that [the Constitution's provisions for jury trial] do not apply to [a] territory ... which has not been incorporated into the Union.").

${ }^{20}$ Id at 298.

${ }^{21}$ Ocampo $v$ United States, 234 US 91, 98 (1914).

22 Dowdell v United States, 221 US 325, 331 (1911).

${ }^{23}$ Dorr, 195 US at 144 (emphasis added) (quoting Mankichi, 190 US at 218).

24 Balzac, 258 US at 310.

${ }^{23}$ Dorr, 195 US at $144-45$.

26 Balzac, 258 US at $312-13$.

27 Downes, 182 US at 277.

${ }^{28} 354$ US 1, 64 (1957) (Harlan concurring). For a recent invocation of Harlan's approach, see Justice Kennedy's concurrence in Verdugo-Urquidez, 494 US at 277-78 (Kennedy concurring).

20354 US at 75 (Harlan concurring).

so Compare id at 70 (Harlan concurring).

${ }^{31}$ Id at 75 (Harlan concurring).
} 
and abstract rule that [Americans overseas must be afforded] all the guarantees of the Constitution," if circumstances would "make adherence to a specific guarantee altogether impractical and anomalous." ${ }^{32}$ Factors such as "the particular local setting, the practical necessities, and the possible alternatives" to strict enforcement of the constitutional provision in question could render that right impractical and anomalous. ${ }^{33}$

Harlan's concurrence in Reid recast the Insular Cases doctrine in several key respects. First, Harlan abandoned the formal inquiry into whether the contested constitutional guarantee is "fundamental." 34 This omission signaled Harlan's shift away from the inherent nature of the contested right when considered in the abstract, and toward the particular local setting involved. ${ }^{35}$ Second, he rejected the Insular Cases' categorical, across-the-board approach to applying constitutional rights to the territories, instead proposing a territory-by-territory analysis. ${ }^{36}$ Unlike White, Harlan would not deny a right to every unincorporated territory simply because the right was too burdensome to apply in any one territory.

Harlan's "impractical and anomalous" test is ambiguous. The word "impractical," for example, may refer either to technical circumstances that make implementing a certain right unfeasible as a logistical matter ${ }^{37}$ or to diplomatic considerations that make enforcing a right overseas politically unwise. ${ }^{38}$ Harlan's use of "anomalous" is even less clear, although he appeared amenable to Justice Frankfurter's focus on those constitutional provisions which "found an uncongenial soil because they ill accorded with the history and habits of [a territory's] people." 39 As the next section will demonstrate, the D.C. and Ninth Circuits have resolved each of these ambiguities in quite different manners.

${ }^{32}$ Id at 74-75 (Harlan concurring).

${ }^{33}$ Id at 75 (Harlan concurring).

${ }^{34}$ See id at 76 (Harlan concurring).

ss Justice White called for an inquiry "into the situation of the territory and its relations to the United States," Downes, 182 US at 293 (White concurring), but this inquiry was to determine whether the territory in question had been incorporated, not whether the contested right was fundamental.

${ }^{38}$ See, for example, Reid, 354 US at 74 (Harlan concurring).

${ }^{37}$ See id at $76 \mathrm{n} 12$ (Harlan concurring).

${ }^{38}$ See id at $77 \mathrm{n} 12$ (Harlan concurring).

${ }^{38}$ See id at 51 (Frankfurter concurring). See also id at 67 (Harlan concurring). 


\section{Territorial Jurisprudence Developed For American SAMOA AND THE NoRTHERn Mariana IsLaNDS}

This section examines how the D.C. and the Ninth Circuits have developed the Supreme Court's legal standards to determine the Constitution's application to different unincorporated territories. Each court has framed its analysis around a different legal standard which it has elaborated in directions not necessarily inherent in the test itself. Moreover, the two circuits have offered widely divergent accounts of Harlan's "impractical and anomalous" standard.

\section{A. The D.C. Circuit's Use of Harlan's Test for American Samoa}

In 1975, a D.C. Circuit panel invoked Harlan's "impractical and anomalous" test, which had been dormant for nearly two decades, as the proper yardstick for measuring the Constitution's application to American Samoa. The United States acquired these South Pacific islands pursuant to an international accord to divide the Samoan archipelago among several imperial powers. ${ }^{40}$ In 1900 , President McKinley proclaimed American authority over the islands, without awaiting the formal consent of the Samoan people. ${ }^{41}$ In 1929, Congress officially gave the President the authority to govern American Samoa. ${ }^{42}$ Since 1951, the Secretary of the Interior has exercised governing authority there upon delegation from the President. ${ }^{43}$

In King $v$ Morton, ${ }^{44}$ the D.C. Circuit examined the constitutionality of American Samoa's historic refusal to provide jury trials to persons prosecuted under territorial law. Jake King, a non-Samoan U.S. citizen living in Samoa, faced prosecution by the American Samoan government for violating its tax code. He filed suit to force the Secretary of the Interior to declare the territory's denial of jury trials unconstitutional. The court first rejected the territory's argument that under the Insular Cases, the right to jury

40 The agreement was entered into at a convention among the United States, Germany, and Great Britain to resolve the disputes between the three governments as to the Samoan Group of Islands. Samoan Convention Agreement, 31 Stat 1878 (1899).

11 President McKinley assumed control over the islands of American Samoa on February 19, 1900. Exec Order 125-A (Feb 19, 1900), reprinted in Samoa Code Ann 6 (1988) as Navy Department Order No. 540. The Samoan high chiefs on two islands formally ceded their lands to the United States three months later. See Samoa Code Ann 2-3 (1982); 48 USC § 1661(a) (1988).

12 Joint Resolution of Feb 20, 1929, 45 Stat 1253, codified at 48 USC § 1661(c) (1988).

43 Exec Order 10264, 3 CFR 764 (Jun 29, 1951).

14520 F2d 1140 (DC Cir 1975). 
trial does not extend to unincorporated territories such as Samoa. ${ }^{45}$ Instead, the circuit remanded the case to the district court, instructing that court to determine "whether in American Samoa 'circumstances are such that trial by jury would be impractical and anomalous." "48

The Samoan government also argued that jury trials could not be implemented in American Samoa without disturbing the native culture and society. For the federal government to require juries in Samoa, it asserted, "would be an . . . inappropriate foreign imposition"47 that would "undercut the preservation of traditional values," 48 and supplant alternative native methods for resolving disputes. $^{49}$ Thus, the Samoan government implicitly argued that the right to a jury trial is "anomalous" in American Samoa and should not be extended to that territory. ${ }^{.0}$

The D.C. Circuit rejected this implied interpretation of the "anamolous" inquiry. Rather than focus on whether the introduction of a right would hamper efforts to protect weakened traditions from further erosion, the court considered a contested right "anomalous" if its implementation would be frustrated by a territory's inhospitable customs and values. ${ }^{51}$ The court stated that Harlan's test "focuses on the applicability of [U.S. constitutional] principles and not on Samoan laws and customs themselves." must be determined "whether the Samoan mores and [chieftain] culture with its strict societal distinctions will accommodate a jury system in which a defendant is tried before his peers," and "whether a jury in Samoa could fairly determine the facts of a case ... without being unduly influenced by customs and traditions of which the criminal law takes no notice." 33

On remand, the district court crowned King's challenge with success. In reaching this holding, the court found that those facets of traditional Samoan society uncongenial to juries had so "eroded

45 King, $520 \mathrm{~F} 2 \mathrm{~d}$ at 1143.

${ }^{46}$ Id at 1147-48, citing Reid, 354 US at 75 (Harlan concurring).

47 Government of American Samoa v King, No App 63-73 (High Ct Am Samoa, App Div, Apr 1, 1974).

48 King $v$ Andrus, 452 F Supp 11, 12-13 (D DC 1977).

49 King, 520 F2d at 1157 (Tamm dissenting). Accord John H. Mansfield, The Religion Clauses of the First Amendment and Foreign Relations, 36 DePaul L Rev 1, 23 (1986) (jury trial may be inconsistent with traditional authority and ways of settling disputes).

so King, 520 F2d at 1156 (Tamm dissenting).

s1 Id at 1147 (ruling that the constitutional inquiry must "rest on a solid understanding of the present legal and cultural developments of American Samoa") (emphasis added).

${ }^{82}$ Id at 1144 (emphasis added).

${ }^{63}$ Id at 1147. 
in the face of western world encroachment" that they would no longer thwart that institution. ${ }^{54}$ It also construed Harlan's "impractical" prong to focus on technical barriers to the implementation of the constitutional right. The court concluded that American Samoa's judicial system could provide jury trials "[f]rom a logistical and administrative point of view," since the islands possessed a sufficient pool of prospective jurors and legal personnel. ${ }^{\mathrm{ss}}$

B. The Ninth Circuit's Application of the Insular Cases to the Northern Mariana Islands

The Northern Mariana Islands ("NMI") consist of sixteen small islands located north of Guam in the Pacific Ocean. The United States began administering the islands in 1947 as a trusteeship for the United Nations. ${ }^{56}$ A process of bilateral negotiation and agreement between the trust territory and the federal government $^{67}$ led to the termination of the trusteeship, and the NMI's emergence as a semi-autonomous "commonwealth" politically united with and under the sovereignty of the United States. ${ }^{58}$ The terms of this arrangement were enshrined in a document known as the commonwealth "Covenant." The Covenant was approved both by the people of the NMI, in plebiscite, ${ }^{60}$ and by the United States Congress. ${ }^{61}$

The Covenant authorizes the government of the NMI to limit trial by jury in criminal prosecutions under local law, ${ }^{62}$ and to restrict the sale of NMI land to persons of native descent. ${ }^{63}$ As in American Samoa, the territorial government sought to curtail juries to accomodate local conditions and experience. ${ }^{64}$ Additionally,

s4 Andrus, 452 F Supp at 14,17 .

${ }^{s s}$ Id at $16-17$.

s8 Trusteeship Agreement for the Former Japanese Mandated Islands, July 18, 1947, Art 3, 61 Stat 3301, TIAS No 1665, 8 UNTS 189.

${ }^{57}$ See Atalig, 723 F2d at 685 n 5.

${ }^{88}$ See Joint Resolution to Approve the Covenant to Establish a Commonwealth of the Northern Mariana Islands, Pub L No 94-241, 90 Stat 263 (1976) ("Covenant"), reprinted as amended in 48 USC $\S 1681$ (note) (1988). The trusteeship terminated a decade after the Resolution's passage. See Proclamation No 5564, 3 CFR 146 (Nov 3, 1986).

s9 Covenant to Establish a Commonwealth in Political Union With the United States of America, reprinted in Covenant, 90 Stat 263, codified at 48 USC $\S 1681$ (note) (1988).

${ }^{80}$ The people of NMI approved the Covenant by a seventy-eight percent margin on June 17, 1975. Atalig, 723 F2d at 685.

61 Covenant, Pub L No 94-241, 90 Stat 263 (cited in note 58).

${ }^{62} \mathrm{Id}, 90$ Stat at $267, \S 501(\mathrm{a})$.

es Id, 90 Stat at $275, \S 805$ (a).

64 Hearings to Approve "The Covenant to Establish a Commonwealth of the Northern Mariana Islands," 94th Cong, 1st Sess 376, 639-40 (1975). 
it sought land alienation restraints to ensure continued ownership of commonwealth land by natives, whose "culture and traditions . . . are uniquely tied to the land."6s The Covenant also purports to excuse these authorizing provisions from federal constitutional restrictions, ${ }^{86}$ and to prohibit their modification without the consent of both the NMI and the United States. ${ }^{67}$

The Ninth Circuit rejected constitutional challenges to both of these policies. It affirmed NMI's limits on trial by jury in Commonwealth of the Northern Marianas Islands $v$ Atalig, ${ }^{68}$ and upheld the NMI's land alienation restraints in Wabol $v$ Villacrusis. ${ }^{69}$ In each case, the court employed the "fundamental rights" test developed in the Insular Cases to frame its analysis. In Atalig, the court read the Insular Cases to hold that the "right to trial by jury [is a] nonfundamental right [] that do[es] not apply in unincorporated territories." Similarly, Wabol examined the validity of the NMI's alienation restraints by asking whether "the right of equal access to long-term interests in Commonwealth real estate [is] a fundamental one which is beyond Congress' power to exclude from operation in the territory ...."11

The Ninth Circuit's version of the "fundamental rights" test, however, departs from White's original formulation by redefining the nature of "fundamental" rights. Unlike the Supreme Court in the Insular Cases, the Ninth Circuit does not invoke natural rights philosophy. Instead, it proposes a more empirical, anthropological inquiry. "In the territorial context," Wabol asserted, "the definition of a basic and integral freedom must narrow to incorporate the shared beliefs of diverse cultures." comes whether the asserted constitutional guarantee "is fundamental in this international sense." 73 The focus of the inquiry is

${ }^{\text {Bs }}$ Wabol $v$ Villacrusis, 908 F2d 411, 414 (9th Cir 1990). Residents of the NMI feared economic development would dislocate the native population, as occurred in nearby Guam, where more than half the private land is now owned by non-natives. See Howard P. Willens and Deanne C. Siemer, The Constitution of the Northern Mariana Islands: Constitutional Principles and Innovation in a Pacific Setting, 65 Georgetown I J 1373, 1406-09 (1977).

${ }^{88}$ Covenant, 90 Stat at 267, $\S 501$ (b) (cited in note 58).

${ }^{67} \mathrm{Id}, 90$ Stat at $264 \S 105$.

es 723 F2d at 690.

${ }^{89} 908$ F2d 411, 421-22 (9th Cir 1990), amended, 1990 US App LEXIS 4474 (9th Cir).

${ }^{70}$ Atalig, 723 F2d at 688 (emphasis added) (citing Balzac, 258 US at 309; Dorr, 195 US at 149; Mankichi, 190 US at 216-18).

${ }^{71}$ Wabol, $908 \mathrm{~F} 2 \mathrm{~d}$ at 421 (emphasis added).

${ }^{2}$ Id.

${ }^{33}$ Id at 422. 
thus descriptive rather than normative, examining whether the right at stake is cherished as fundamental across various cultures. ${ }^{74}$

The Wabol court applied this analysis to the NMI's land alienation restraints. It concluded that the right of equal access to land acquisition is not "fundamental" in the NMI because the NMI and United States do not mutually consider this right to be inalienable. As the court stated:

Where land is so scarce, so precious, and so vulnerable to economic predation, it is understandable that the islanders' vision does not precisely coincide with mainland attitudes toward property and our commitment to the ideal of equal opportunity in its acquisition. ${ }^{75}$

While the Ninth Circuit has generally employed the "fundamental rights" test to frame its inquiry, the Wabol panel also invoked Harlan's approach (via the D.C. Circuit's King opinion) to supplement its analysis. The Ninth Circuit noted that the "impractical or anomalous" test "sets forth a workable standard for finding a delicate balance between local diversity and constitutional command, and one which is consistent with the principles we stressed in Atalig." "No (Note that the court connected the words "impractical" and "anomalous" with an "or" rather than an "and." This was not an accident, as I argue below.) As expounded by Wabol, this "impractical or anomalous" inquiry focuses on three concerns: whether introducing a contested right into a territory would thwart efforts to protect local culture and values and to preserve the native social system; whether the right's application would impair the United States' ability to form political unions and other advantageous arrangements with territories; and whether introducing the right would force the United States to break international commitments. ${ }^{77}$

Applying these standards, the Wabol court concluded that requiring equal access to long-term interests in NMI land would be impractical and anomalous. ${ }^{78}$ The court found that the land alienation restraints "are properly viewed as an attempt... [to] pro-

34 One way to determine whether a right is fundamental in this sense is to examine international human rights law, which may provide "a uniform minimum standard of rights that can be agreed upon, notwithstanding cultural diversity." Neuman, 100 Yale L $J$ at 980 $81 \mathrm{n} 420$ (cited in note 18).

${ }^{75}$ Wabol, $908 \mathrm{~F} 2 \mathrm{~d}$ at 424.

${ }^{76}$ Id at 422.

77 Id.

${ }^{88}$ Id. 
tect[] local culture and values." cally compelled to curtail land ownership in order to convince the NMI people to accede to United States sovereignty. "Absent the alienation restriction," said the court,

the political union [between the United States and the NMI] would not be possible. Thus, application of the constitutional right could ultimately frustrate the mutual interests that led to the [NMI] Covenant. It would also hamper the United States' ability to form political alliances and acquire necessary military outposts. ${ }^{80}$

Finally, the court noted that the United States undertook to preserve NMI culture and land in the Trusteeship Agreement with the United Nations. For this reason, the Wabol court determined that "[i]t would truly be anomalous to construe the equal protection clause to force the United States to break its [international] pledge ....."81

\section{A Legitimacy-Focused Approach to Territorial JURISPRUDENCE}

The preceding section indicates that the D.C. and Ninth Circuits' territorial decisions diverge widely in both methodology and result. There are at least two ways to explain this occurrence. The confused state of the Supreme Court's own territorial jurisprudence may be the primary cause of the circuit split. Alternatively, the divergence between the D.C. and Ninth Circuits may reflect a judicial debate about the legitimacy of the United States' authority over its various territories. This section exposes the fatal deficiencies of the former approach, and lays out the theoretical and historical foundations of the latter.

\section{A. The Deficiencies of the Doctrinal Explanation}

The Supreme Court's doctrinal confusion is, perhaps, the most evident explanation of the divergence between the circuits. The Court's failure to adopt a single, clear test for identifying which constitutional provisions apply to any given unincorporated territory has left the circuits free to adopt one or the other of the Court's two tests. The Circuits have employed these competing 
standards, moreover, to reach opposing decisions on an identical issue-whether the right to jury trial applies overseas. Surely there must be some connection between the disorder above and the inconsistency below.

Although this strictly formal analysis indicates one factor that has contributed to the circuit split, it cannot unravel the knottiest issues raised by these cases. More to the point, the case law contains three mysteries which cannot be solved by looking at the Supreme Court's jurisprudence alone. First, why did the two circuits select different legal tests for determining the Constitution's territorial extent in the first place? Formal legal analysis suggests that these choices are simply a matter of arbitrary taste.

Second, why has each circuit developed its legal test of choice far beyond its original contours? The Ninth Circuit has applied the "fundamental rights" test to exempt territories from an even larger array of constitutional guarantees than the Insular Cases Court might have countenanced. The Insular Cases Court exempted offshore territories only from those constitutional provisions mandating "procedural" rights peculiar to Anglo-American criminal justice. The Ninth Circuit, by contrast, impaired the "substantive" right of equal access in acquiring land, which is guaranteed by the Equal Protection Clause. Similarly, the D.C. Circuit may have carried the "impractical and anomalous" test further than Justice Harlan would have allowed. Harlan was prepared to jettison jury trials for non-capital offenses committed in American enclaves in England, as well as for any crimes committed in Puerto Rico. ${ }^{82}$ In contrast, the D.C. district court required juries in American Samoa, a place more distant and undeveloped than either Puerto Rico or our enclaves in the United Kingdom. While a formal legal analysis can at least suggest why the two circuits have adopted different tests (i.e., because the choice was there), it cannot explain how each has developed its respective approach.

The final mystery is why the two circuits have offered such widely different interpretations of the "impractical and anomalous" test. (The Ninth Circuit, it will be recalled, used Harlan's standard to supplement its "fundamental rights" analysis.) In applying the "anomalous" prong, the D.C. courts asked whether the territory's culture and values would frustrate the operation of the constitutional right. The Ninth Circuit, by contrast, asked whether introducing a right would thwart efforts to protect a territory's na-

${ }^{82}$ See Reid, 354 US at 75-76 (discussing Balzac, 258 US 298). 
tive culture and values. ${ }^{83}$ The D.C. district court understood the "impractical" prong as emphasizing technical factors that might make implementing a right too difficult as a logistical matter. ${ }^{84}$ The Ninth Circuit, in comparison, focused on the moral and diplomatic concerns that might make a right's introduction politically unwise or embarrassing. ${ }^{85}$ Finally, the D.C. Circuit connected the two prongs of Harlan's test with an "and" (i.e., "impractical and anomalous"), whereas the Ninth Circuit used an "or."

These two interpretations of the "impractical and anomalous" standard are so disparate as to warrant branding Harlan's approach the doctrinal equivalent of Rorschach's inkblot. The inconsistency suggests that even if the Supreme Court had articulated only one test for applying the Constitution overseas, lower courts would have interpreted it differently so as to make it functionally multiform. The enormous gulf between their versions of the same test suggests that a formal legal analysis cannot explain the case law. To fully understand what is occurring, we must recognize how the circuits use the tests to legitimate the exercise of American power over the territories.

\section{B. A Legitimacy-Focused Approach to Territorial Case Law}

A better way to understand this divergence between the circuits is to view it as a judicial dispute over how to bolster the legitimacy of the United States' territorial authority. Presenting this argument in its most persuasive form requires a brief digression into political theory and constitutional history.

According to America's public philosophy, government justifies its exercise of political power over individuals on the basis of two broad legitimizing principles or systems: democracy and liberal constitutionalism. Democratic government derives its legitimacy from the formal consent and ongoing participation of the governed, who are considered the ultimate source of political authority. ${ }^{\mathbf{8 6}}$ Constitutional government is a government created and limited by its constituent act. In the United States, constitutionalism means a liberal or rights-based regime which limits government in favor of individual rights and liberties.

33 Wabol, 908 F2d at 1391.

B4 Andrus, 452 F Supp at 16.

ss Wabol, $908 \mathrm{~F} 2 \mathrm{~d}$ at 423.

8s See, for example, the Declaration of Independence: "Governments are instituted among Men, deriving their just Powers from the Consent of the Governed." 
These two great principles each explain the individual's obligation to obey government in slightly different ways. Democratic theory holds that a person is obliged to obey only those rulers to whom she has given her consent. ${ }^{87}$ Constitutional theory asserts that a person must obey a government only if that government itself complies with the law. ${ }^{88} \mathrm{~A}$ government based on liberal principles, moreover, must also satisfy a substantive condition: it must respect its subjects' fundamental rights, protecting them even against the wishes of temporary majorities.

Generally speaking, the United States government bases its legitimacy on both principles. The federal government's powers are limited by a constitution that demands respect for individual rights. This constitution, in turn, is grounded on the authority of popular consent-ordained and established by "We, the People."

\section{The Original Territorial Framework}

On paper, the United States' territorial authority appears to defy the principles of both 'rights-based constitutionalism and democracy. The Territorial Clause, the Constitution's sole mention of territories, gives Congress "Power to ... make all needful Rules and Regulations respecting the Territory ... belonging to the United States." ${ }^{\circ 0}$ Taken literally, this Clause contradicts the idea of limited government, since it specifies no restraints on Congress's power over territories. The Clause is potentially anti-liberal as well, if it gives Congress the discretion to deny territorial inhabitants fundamental rights. Lastly, the Clause appears anti-democratic as it seems both to deny territorial peoples the residual sovereignty reserved to state inhabitants by the Tenth Amendment, ${ }^{91}$ and to make possible Congress's permanent control of the territories.

In practice, however, the United States' first century of territorial governance generally comported with the demands of both

\footnotetext{
${ }^{8 z}$ See, for example, Michael Walzer, Obligations: Essays on Disobedience, War, and Citizenship x (Harvard, 1970).

88 The relationship between a constitutional regime and its subjects is thus said to be one of mutuality. See, for example, Verdugo-Urquidez, 494 US at 284-85 (Brennan dissenting). Individuals who submit to this regime in turn become entitled to demand their reciprocal rights. See Neuman, 100 Yale L J at 987 (cited in note 18).

so US Const, Preamble.

${ }^{\circ}$ US Const, Art IV, § 3, cl 2.

91 US Const, Amend X ("The powers not delegated to the United States by the Constitution, nor prohibited by it to the States, are reserved to the States respectively, or to the people.").
} 
liberal constitutionalism and democracy. The Supreme Court softened the anti-liberal tendencies of the Territorial Clause by according territorial inhabitants a full complement of personal and civil constitutional rights. ${ }^{92}$ The federal government eliminated the anti-democratic aspects of territorial status in the long run by promising each territory eventual statehood. ${ }^{93}$ To join the federal union, a new state would ratify the Constitution and thereby the government it created, and acquire the rights and sovereignty held in abeyance during its period of territorial tutelage. Thus, in an age when territories became states almost as a matter of course, the anti-democratic aspects of territorial governance liquidated themselves by design. Viewing the territories' eventual statehood as a constitutional certainty, ${ }^{94}$ the Court felt no need to cure the temporarily undemocratic nature of such rule. ${ }^{95}$

\section{The Constitutional Significance of the Spanish-American $\mathrm{War}^{96}$}

After the Spanish fleet, the second major casualty of the Spanish-American War of 1898 was the United States' original plan for territorial development. In the wake of that war, the United States acquired the Philippines, Puerto Rico, Guam, and American Samoa. Unlike earlier acquisitions in North America, these distant offshore territories were widely seen as ineligible for eventual

92 See, for example, Thompson v Utah, 170 US 343, 347 (1898), overruled on other grounds by Williams v Florida, 399 US 78 (1970); Collins $v$ Youngblood, $110 \mathrm{~S}$ Ct 2715 (1990); Scott v Sanford, 60 US (19 Howard) 393, 450-51 (1857) (Taney opinion). But compare American Publishing Co. v Fisher, 166 US 464, 466 (1897); Late Corporation of Church of Jesus Christ of Latter-Day Saints v United States, 136 US 1, 44 (1890). More generally, see Neuman, 100 Yale L J at 953-57 (cited in note 18).

क3 See US Const, Art IV, \& 3, cl 1 ("New States may be admitted by the Congress into this Union . . . ."). This policy was first announced by the quasi-constitutional Northwest Territory Ordinance of 1787 , which envisioned eventual statehood for all of the Northwest Territory (incorporated by the First Congress in the Act of Aug 7, 1789, ch 8, 1 Stat 50); Arnold H. Liebowitz, Defining Status: A Comprehensive Analysis of United States Territorial Relations 6-10 (Martinus Nijhoff, 1989).

o4 See, for example, Scott, 60 US (19 Howard) at 446:

There is certainly no power given by the Constitution to the Federal Government to establish or maintain colonies bordering on the United States or at a distance, to be ruled and governed at its own pleasure; nor to enlarge its territorial limits in any way, except by the admission of new States.

${ }^{95}$ See, for example, National Bank v County of Yankton, 101 US 129, 133 (1879) ("[Congress] may make a void act of the territorial government valid, and a valid act void.").

${ }^{96}$ My apologies to Bruce Ackerman, We The People: Foundations 37 (Belknap, 1991) ("[N]obody talks much about the constitutional significance of the Spanish-American War"). 
statehood. ${ }^{97}$ Because of their demography, many feared that their admission to the Union as states would disrupt the racial, linguistic, and cultural character of the national community. ${ }^{98}$ Some also argued that their inhabitants were either unprepared or undeserving of certain "Anglo-Saxon" rights guaranteed by the Constitution. ${ }^{99}$

The Insular Cases doctrine-that not every provision of the Constitution automatically applies to unincorporated territories-reflected the temper of the times. ${ }^{100}$ In many ways, this new doctrine razed the United States' pre-1898 structure for legitimizing its territorial governance. The Insular Cases Court defied democratic norms by sanctioning the United States' assertion of total governing power over peoples without first seeking their consent. ${ }^{101}$ The Court also curtailed constitutionalism by excusing the federal government from some of the Constitution's facial limitations. Finally, these decisions compromised liberal values by denying individual rights otherwise secured by the Constitution.

Having made these concessions to imperialism, the Insular Cases Court nonetheless attempted to square the post-1898 territorial system with America's traditional legitimizing principles. First, it professed fealty to constitutionalism and rule of law by proclaiming that "the Constitution is operative" in the territories. ${ }^{102}$ Such constitutionalist utterances, however, were more rhetorical than real. Many were heartened, no doubt, to learn that the

${ }^{97}$ See Balzac, 258 US at 311; Downes, 182 US at 282.

98 Versions of this argument can still be heard in semi-polite company. See, for example, Patrick Buchanan, quoted in Newsweek 17 (Dec 23, 1991) ("[I]f we had to take a million immigrants in, say, Zulus next year, or Englishmen, and put them in Virginia, what group would be easier to assimilate and would cause less problems . . . ?").

"See, for example, Charles C. Langdell, Thé Status of Our New Territories, 12 Harv L Rev 365, 386 (1899).

${ }^{100}$ See Juan R. Torruella, The Supreme Court and Puerto Rico: The Doctrine of Separate and Unequal 39 (Editorial de la Universidad de Puerto Rico, 1985) (McKinley's victory over William Jennings Bryan in the election of 1900 seen as plebiscite in favor of territorial expansion and for giving the federal government a free hand in governing the new territories). See also Finley Peter Dunne, The World of Mr. Dooley 89 (Collier 1962) ("No matther whether th' constitution follows th' flag or not, th' supreme coort follows th' iliction returns.").

101 Only in American Samoa did the United States seek a formal expression of the native population's consent to its rule, and this consent was not sought until the U.S. had already asserted control over the islands. Even then, Congress did not formally acknowledge this expression of consent until three decades later. See 48 USC $\S 1661$ (a) (1929).

${ }^{102}$ Downes, 182 US at 292. See also Dorr, 195 US at 140; Coudert, 26 Colum L Rev at 849 (cited in note 9) (piously asserting that such an approach was consistent with Americans' deep "reverence for the Constitution and its all-embracing wisdom ....."). 
Constitution did indeed "follow" the flag overseas. ${ }^{103}$ But what was the point if some of its provisions nonetheless had to stay at home? In a more substantive vein, the Court demanded that United States territorial rule conform with liberal principles by respecting the "fundamental" rights of territorial inhabitants, as defined by natural rights philosophy.

Most audacious, however, was the Court's attempt to recast its denial of constitutional rights to territorial inhabitants as consistent with democratic theory. Because statehood, the traditional solution to the anti-democratic character of territorial governance, was unlikely for the new territories, the Court felt compelled to package unincorporated status as a vehicle for limited, local selfdetermination. The justices asserted that the peoples of the newlyacquired territories might not desire those constitutional guarantees "peculiar to Anglo-Saxon jurisprudence"104 that clashed with native customs and values. To force rights upon an unwilling people, the court stated, would be positively unjust because it would hinder them from ordering their institutions in a way more faithful to their traditional ways. ${ }^{105}$ By exempting territories from such unfamiliar rights as jury trials, the Insular Cases Court claimed that it was providing territorial peoples with more latitude to protect their traditional way of life through democratic decisionmaking. ${ }^{106}$

\section{Using a Legitimacy-Focused Approach to Explain the Lower Courts' Decisions}

This section argues that the Supreme Court's territorial jurisprudence has established a framework within which the lower courts may act to bolster the legitimacy of American dominion in each particular territory. In rhetoric, federal courts pledge allegiance to the rule of law and to the principle of constitutionalism. On a deeper level, however, they search for that combination of

103 But not all. See Langdell, 12 Harv L Rev 365 (cited in note 99) (arguing that congressional limitations apply only to the states); James Bradley Thayer, Our New Possessions, 12 Harv L Rev 464, 467 (1899) (claiming that the Constitution grants to the federal government "the legal, constitutional power to govern these islands as colonies, substantially as England might govern them").

10. Downes, 182 US at 283.

105 "[T]he United States has been liberal in granting to the Islands acquired by the Treaty of Paris most of the American constitutional guarantees, but has been sedulous to avoid forcing a jury system on a Spanish and civil-law country until it desired it." Balzac, 258 US at 311. See also Michael Walzer, Spheres of Justice: A Defense of Pluralism and Equality 313 (Basic, 1983) ("[a] given society is just if its substantive life is lived . . . in a way faithful to the shared understandings of its members").

${ }^{106}$ Balzac, 258 US at 310 (emphasis added). 
democratic and liberal principles they believe most suited to a given territory, in light of its historic and legal relationship with the United States. Because each of these relationships is unique, the amalgam may vary from territory to territory, so that one setting may require more room for local self-determination, while another may require stricter enforcement of constitutional rights.

\section{A. The Ninth Circuit's Legitimacy Framework for the NMI}

To legitimate the United States' authority over the NMI, the Ninth Circuit has followed the approach introduced by the original Insular Cases Court.. On the surface, the circuit has endorsed constitutionalism, stating that "Congress' powers derive from and are defined and limited by the Constitution." 107 Yet, at the same time, it has subordinated the constitutional rights of individuals to the democratic desires of territorial inhabitants. In this manner, then, the approach enhances the democratic and communitarian pedigrees of American rule, though at the cost of compromising its fidelity to liberal constitutionalism.

The Ninth Circuit justifies the United States' exercise of governing power over the Northern Mariana Islands by referencing the political and legal basis of our present authority there. The people of the NMI, it will be recalled, solemnly and formally acceded to the United States' sovereignty. As a precondition to their consent, however, they sought exemption from certain requirements of the Constitution and demanded that the federal government not disturb such exemptions unilaterally. ${ }^{108}$ The NMI community sought to loosen the constitutional yoke in order to secure more space for the unique and fragile aspects of their culture. The federal government essentially promised the NMI people that the Constitution's provisions would apply to them only to the extent provided for and agreed to in the Covenant.

The Ninth Circuit, as its opinions reveal, is keenly aware that the United States' authority over the NMI is grounded on the consent of the NMI people. Both Atalig and Wabol asserted that determining the Constitution's reach "requires an understanding of the unique political relationship between the NMI and the United States." ${ }^{109}$ In detailing this relationship, both decisions referred to Article 6 of United Nations Trusteeship Agreement, in which the

\footnotetext{
107 Wabol, 898 F2d at 1390 (citation omitted).

${ }^{108}$ See notes 56-67 and accompanying text.

${ }^{109}$ Atalig, $723 \mathrm{~F} 2 \mathrm{~d}$ at 684. See also Wabol, $908 \mathrm{~F} 2 \mathrm{~d}$ at 420.
} 
United States undertook to "promote the development of the inhabitants of the trust territory toward self-government or independence, [according to the] freely expressed wishes of the peoples concerned."110 The opinions also discussed at length the Covenant whereby the NMI acceded to United States sovereignty, and noted that this document was democratically approved both by the territorial legislature and by the NMI people directly. ${ }^{111}$ Citing these documents, Atalig stated that "the NMI possesses a right to selfgovernment." 112

The Ninth Circuit, moreover, acknowledges the conditional nature of the NMI's consent to American control, and the promises that the United States made to the NMI people in order to secure their consent. By repeatedly stressing the importance of these promises, the court conveyed its deep desire to avoid abrogating them. Wabol and Atalig both observed that the NMI and the United States would not have been politically tied without the Covenant's provisions authorizing alienation restraints and waiving jury trials. ${ }^{13}$ For this reason, Wabol continued, "application of the constitutional right could ultimately frustrate the mutual interests that led to the Covenant."114

As the above discussion suggests, the Ninth Circuit believes that American rule over the NMI derives its legitimacy from the consent of the NMI people and from the United States' respect for the NMI's unique customs and values. As a result, the court has concluded that certain constitutional rights at odds with local ways need not be strictly applied there, provided that the territorial inhabitants themselves demanded release from such rights.

To give effect to the local majority's wishes, the Ninth Circuit denied to the NMI people what might otherwise have been their constitutional right to trial by jury. Simliarly, the court denied some NMI inhabitants (i.e., emigrants to the NMI from the U.S.) but not others (i.e., natives) the equal right to purchase territorial land. Thus, to bolster the democratic source of the United States' authority in the NMI, the court compromised liberal constitutionalist bases of political legitimacy. As in the Insular Cases, this translates into diminished judicial protection for individual rights.

110 Atalig, 723 F2d at 684-85 (emphasis added) (citing the Trusteeship Agreement for the Former Japanese Mandated Islands, Art 6.) See also Wabol, 908 F2d at 420.

111 Atalig, 723 F2d at 685; Wabol, 908 F2d at 420.

112 Atalig, $723 \mathrm{~F} 2 \mathrm{~d}$ at 687 (emphasis added).

113 See Wabol, 908 F2d at 423; Atalig, 723 F2d at 685-86.

114 Wabol, 908 F2d at 423. 
Yet, such an outcome seems a necessary consequence of the court's pro-democracy stance.

B. The D.C. Circuit's Legitimacy Framework for American Samoa

The D.C. Circuit, like the Ninth Circuit, juxtaposes democratic sources of legitimacy with liberal constitutional ones. The D.C. courts, however, reverse the legitimacy equation accepted by the Ninth Circuit, compelling stricter enforcement of constitutional rights, and rejecting local demands to set aside constitutional commands.

In King, the D.C. Circuit refused to let local wishes influence whether the Constitution required jury trials in American Samoa. The answer to this question, the panel declared, "is [not] to be found in the failure of the Samoan Constitution, originated by the Samoan people, to provide for trial by jury in criminal cases."115 The D.C. judiciary did not ignore the force of democratic claims. ${ }^{116}$ It did, however, hold that it is the judiciary's responsibility to decide which constitutional provisions apply to territories; a territorial community's desires are, at best, ancillary to the court's inquiry. ${ }^{117}$

The D.C. courts decision to permit constitutional rights to trump the democratic and communitarian desires of American Samoans goes against the tenor of the Insular Cases. To explain this outcome, we must look to the unique legal relationship between the islands and the United States. As a formal matter, the United States' governance of American Samoa resembles an executive fiefdom. Pursuant to both presidential order and federal statute, the Secretary of the Interior exercises "all civil, judicial, and military powers" of government in American Samoa. ${ }^{118}$ From a legal perspective, therefore, the Secretary is the sole source of lawful authority on the islands. The people of American Samoa, unlike those of the NMI, have no acknowledged legal right to govern themselves.

Given this legal environment, the D.C. courts have reinforced the legitimacy of the United States' authority over American Sa-

\footnotetext{
${ }_{115}$ King, $520 \mathrm{~F} 2 \mathrm{~d}$ at 1147 (emphasis added).

126 Andrus, $452 \mathrm{~F}$ Supp at 12 (emphasizing that these questions should ideally be resolved by American Samoans themselves).

117 Id (the views of Samoans do not themselves establish dispositively the impracticality or anomaly of a jury trial).

${ }^{118}$ See 48 USC § 1661(c) (1988); Exec Order No 10264, 3 CFR 764 (Jun 29, 1951).
} 
moa by underscoring the constitutional limits on the Secretary's power, and by assuring the exercise of that power within those limitations. To this end, the courts require the Secretary to administer American Samoa in accordance with the Constitution. Thus, the Secretary must review the native government's compliance with constitutional standards. ${ }^{119}$ "[T]he door of the [federal] district court," the D.C. Circuit declared in King, "cannot be shut to Samoan plaintiffs properly challenging the lawfulness of the actions of an official of the United States government."120 Lacking a legal basis to give effect to local wishes, the courts require the Secretary to administer even constitutional protections that the Samoan people seem content to forgo.

\section{Unlocking the Three Mysteries}

This section will show how the lower courts' desire to reinforce the legitimacy of United States territorial authority has led them to develop territorial jurisprudence along such divergent paths. More precisely, this section uses a legitimacy-focused analysis to unlock the three mysteries which a more formal legal analysis could not crack. In each instance, the two circuits have selected and interpreted the Supreme Court's precedents in a way that advances their view as to what validates the United States' assertion of power over a particular territory.

1. Why have the circuits adopted different tests?

The Ninth Circuit's decision to use the Insular Cases' "fundamental rights" test as the cornerstone of its analysis coincides with its account of what justifies the United States' authority over the NMI: that the inhabitants of the islands consented to such authority on the condition that the United States respect their traditional ways. On a theoretical level, the Ninth Circuit shares the Insular Cases' view that unincorporated status can serve as a vehicle for limited local self-determination, i.e., by permitting unincorporated offshore communities to forgo "nonfundamental" constitutional protections that clash with native customs. As the Wabol court asserted, an analysis of the Constitution's application to un-

\footnotetext{
119 See Corp. of Presiding Bishop of Church of Jesus Christ of Latter-Day Saints v Hodel, 637 F Supp 1398, 1413 n 29 (D DC 1986); Corp. of Presiding Bishop of Church of Jesus Christ of Latter-Day Saints v Hodel, 830 F2d 374, 384 (DC Cir 1987). But compare the Revised Constitution of American Samoa, Art III, §§ 1-3 (1967) (not providing for judicial review by U.S. courts).

${ }_{120}$ King, 520 F2d at 1144.
} 
incorporated territories "must be undertaken with an eye toward preserving Congress's ability to accommodate the unique social and cultural conditions and values of the particular territory."121

As a practical matter, the "fundamental rights" test may give the Ninth Circuit more licence to dispense with culturally jarring constitutional provisions. As we have seen, the "fundamental rights" test invites courts to contemplate whether a contested right is "fundamental" according to open-ended extra-constitutional criteria. Because the inquiry is so speculative and abstract, it arguably imposes fewer constraints on the courts' ability to impair rights overseas.

In contrast to the "fundamental rights" test, Justice Harlan's "impractical and anomalous" approach seems less suited to the Ninth Circuit's democratic and communitarian agenda. Unlike the Insular Cases Court, Harlan did not invite territorial people to praticipate in determining which constitutional provisions will apply to their territory. Moreover, Harlan's test arguably makes it harder for courts to dispense with constitutional rights overseas, even if territorial inhabitants so desire. Unlike the Insular Cases, which presume that rights deemed "nonfundamental" in one setting do not apply in other unincorporated areas as well, Harlan's test presumes that every constitutional right applies to every territory. To overcome this presumption, the government must show that introducing a specific right would be too burdensome in the given setting.

A legitimacy-focused analysis can also explain why the D.C. Circuit adopted Harlan's standard-rather than the "fundamental rights" test to frame its constitutional inquiry. The D.C. judiciary believes that the United States' rule over American Samoa, which lacks formal democratic sanction, is legitimated by the federal government's adherence to constitutional limits. The "impractical and anomalous" standard comports with this theory because it connotes a more extensive application of the Constitution overseas. Moreover, Harlan's approach does not expressly countenance the impairment of constitutional rights to advance purely communitarian goals. In both of these ways, the "impractical and anomalous" test facilitates the D.C. Circuit's efforts to conform territorial rule to liberal constitutional principles and to resist popular demands to dispense with certain individual rights. 
2. Why have the circuits modified their tests extensively?

While the Supreme Court's two territorial tests are each sufficiently substantive to explain the lower courts' selection of one over the other, the significance of the tests should not be overstated. As shown earlier, the two circuits have each developed their respective approaches beyond their original contours. The D.C. judiciary extended the right to a jury trial overseas further than Harlan himself might have endorsed. Conversely, the Ninth Circuit expanded the "fundamental rights" standard to bar the application of an even wider array of constitutional rights than contemplated by the Insular Cases Court.

An analysis that focuses on the way in which the law legitimates the United States' territorial authority can readily explain these developments. The D.C. Circuit narrowly construed the "impractical and anomalous" exception in order to afford the people of American Samoa maximum constitutional protection against their government. This construction enhances efforts to conform the United States' governance of Samoa to liberal constitutional norms. Since American authority there derives its legitimacy from adherence to federal constitutional law, the D.C. courts have felt compelled to give that law serious bite. Similarly, the Ninth Circuit has classified fewer rights as "fundamental"-and hence automatically applicable overseas-than the Insular Cases Courts so as to give the NMI maximum latitude to structure their laws and institutions.

3. Why have the circuits offered contradictory accounts of Harlan's test?

Finally, the legitimacy-based approach better explains why the two circuits assigned conflicting meanings to each word of Harlan's "impractical and anomalous" test. The D.C. Circuit construed each word in the most rights-protective manner possible. It read the two prongs of Harlan's test in the conjunctive so that a constitutional guarantee must be both impractical and anomalous in order to avoid application overseas. It imposed nearly insuperable logistical hurdles to justify waiver of that right, in addition to a native culture whose values would actively frustrate the right's operation. As argued above, this interpretive stance reinforces the liberal constitutionalist pedigree of the United States authority in American Samoa.

In contrast, the Ninth Circuit has read Harlan's test in a way that allows democratic and communitarian interests to prevail over 
constitutional mandates. First, the court read the two prongs in the disjunctive, ${ }^{122}$ so that a showing of either impracticality or anomalousness will render a right inapplicable in the territory. The court understood "impractical," moreover, to focus on the political costs of abrogating promises to territorial peoples to waive certain constitutional requirements. Finally, it found a constitutional right "anomalous" when application of that right is likely to weaken traditional values. ${ }^{123}$ This reading of the precedents provides the inhabitants of the NMI with more democratic space to enact communitarian policies.

\section{Making Legitimacy an Explicit Goal of Territorial JURISPRUDENCE}

In the preceding sections, the Comment has exposed the extra-legal concerns that have driven the lower courts' development of territorial jurisprudence. Their diverging elaborations of this jurisprudence reflect the fact that the United States justifies its authority over different territories on different grounds-stressing the inhabitants' consent to American dominion in one place; the constitutional limits on American control in another. As a result, lower federal courts have culled and crafted the Supreme Court's territorial precedents to reflect these varying moral and political realities.

This analysis suggests a rather unorthodox conclusion: the legal split between the circuits should not be closed. Doctrinal diversity in territorial jurisprudence is a good thing because it permits federal courts to maximize the legitimacy of the United States' rule in each territory. "Trust Territories are sui generis," the Ninth Circuit has declared, so that "[e]ach one must be viewed independently to determine the rights granted to its citizenry ...."124 The same can be said for each of our offshore territories, with whom the United States has a unique history and relationship. Because the various territories are differently situated, a single formula for legitimizing governance over all of them may be either impossible or foolish. For this reason, the Supreme Court's malleable territorial doctrine serves a valuable function; it gives lower courts the latitude to devise the proper combination of legitimizing principles appropriate for each territory.

\footnotetext{
${ }^{122}$ Wabol, $908 \mathrm{~F} 2 \mathrm{~d}$ at 422.

123 Id at 423 .

124 Fleming v Department of Public Safety, 837 F2d 401, 404 (9th Cir 1988).
} 
Courts might take this insight a step further by revising territorial doctrine to recognize expressly the two competing theories of legitimacy that have heretofore driven its development from the outside. Such an account could be fashioned along the following lines: In those territories which the United States formally governs through the unilateral assertion of its authority, ${ }^{125}$ the federal government (and its instrumentality, the territorial government) ${ }^{226}$ must follow the rule of law, in both word and deed. In doctrinal terms, this would mean that every personal right guaranteed by the Constitution must be extended to such territories, unless a right's application proves to be both impractical and anomalous (as defined by the D.C. Circuit for American Samoa). In those territories where United States power formally emanates from the consent of the inhabitants, ${ }^{127}$ on the other hand, the federal government must generally honor the conditions of the compact through which it secured that consent. Doctrinally, this would mean that while certain "fundamental" rights (as defined by the Ninth Circuit for the NMI) must be extended to such territories, the native inhabitants could otherwise demand, as a precondition to American dominion, the ouster of certain "nonfundamental" constitutional rights that clash with their native customs and ways.

This bifurcated approach indicates that the Ninth Circuit properly employed the "fundamental rights" test to determine the constitutionality of the NMI's jury trial denial and land alienation restraints. To promote the democratic legitimacy of American dominion, courts should respect the desire of the NMI people to opt out of these arguably nonfundamental provisions of the Constitution that are at odds with their traditional way of life. Similarly, it appears that the D.C. Circuit correctly applied the "impractical and anomalous" test to decide whether the Constitution required jury trials in American Samoa, a territory where the United States does not base its legal authority on the consent of the inhabitants.

Under this two-track scheme, the appropriate test will not only differ from territory to territory, it may also alternate within a single territory, depending upon the constitutional provision at issue. In the case of the NMI, for example, federal courts should only apply the "fundamental rights" test to those constitutional guarantees which the NMI expressly rejected as a precondition to

\footnotetext{
125 American Samoa, Guam, the Virgin Islands.

${ }^{128}$ See, for example, United States $v$ Wheeler, 435 US 313, 321 (1978) (Guam's territorial government is "entirely the creation of Congress").

${ }_{127}$ The Northern Mariana Islands and Puerto Rico.
} 
its consent to American rule. For all other constitutional rights courts should ask whether the impugned guarantee would be "impractical and anomalous" to implement in the NMI, as understood by the D.C. Circuit. Otherwise, the NMI government could cavalierly deny its citizens any federal constitutional right deemed "nonfundamental" according to some extra-constitutional standard (such as international human rights law or natural rights philosophy), merely as a matter of local statute.

Likewise, in the case of American Samoa, federal courts should refrain from employing the "impractical and anomalous" test across the board. This is because circumstances exist in that territory which warrant a limited application of the "fundamental rights" standard. When the leaders of American Samoa acceded to United States sovereignty at the turn of the century, they requested, ${ }^{128}$ and ultimately received, a congressional promise to respect and protect native land ownership. ${ }^{129}$ (Samoan leaders made no such demand for their native procedures of criminal justice.) In furtherance of this promise, the territorial government has confined the purchase of Samoan land to those of native descent. ${ }^{130}$ To determine the constitutionality of these alienation restraints, therefore, federal courts should adopt the more democratic, communitarian outlook captured by the "fundamental rights" approach. American Samoa has stronger moral and political grounds to demand judicial endorsement of its land laws than it did for its no-jury policy.

\section{CONCLUSION}

While the current state of territorial law has its redeeming features, the situation is not optimal. In many ways, territorial jurisprudence has never really recovered from the aftermath of the Spanish-American War. Prior to 1898, the United States' territorial enterprise generally satisfied the demands of both liberal constitutional and democratic theory. Since then, the federal courts have struggled to salvage such legitimacy as they can from the wreckage of the prior framework of justification. But as the experi-

128 Deed of Cession of Tutuila and Aunuu (Apr 17, 1900) ("The Government of the United States of America shall respect and protect the individual rights of all people dwelling in Tutuila to their lands . . .."); Deed of Cession of Manu'a Islands (Jul 26, 1904) ("the rights of the Chiefs in each village and of all people concerning their property according to their customs shall be recognized").

12948 USC $\S \S 1661(\mathrm{a})-1661(\mathrm{~b})$.

130 See Am Samoa Code $§ 37.0204$ (b), authorized by Rev Const of Am Samoa, Art I, § 3 . 
ence of the two circuits reveals, such efforts are doomed to partial success at best. Expanding the democratic legitimacy of American dominion, as in the NMI, can only come at the expense of liberal constitutional validity. Similary, rigid enforcement of certain constitutional rights overseas, as in American Samoa, means less scope for local decisionmaking and cultural preservation. Even if a territory minimizes the internal conflict between these principles (as has Puerto Rico), ${ }^{131}$ it will still be denied full and effective democratic participation in its overarching sovereign, the federal government. ${ }^{132}$

For the near future, federal courts have no choice but to struggle with the legal legacy of the nation's fleeting quest for imperial glory. This predicament will persist unless the United States casts off the last remnants of empire. ${ }^{133}$ And until then, the fault lies not in our courts, but in ourselves that we are overlords. ${ }^{134}$

${ }^{131}$ The residents of Puerto Rico, like those of the NMI, have formally ratified their relationship with the United States through a bilateral compact. See Resolution 34 (approved by the Constitutional Convention of Puerto Rico in the Plenary Session held July 10, 1952), reprinted in Documents on the Constitutional History of Puerto Rico 196 (Office of the Commonwealth of Puerto Rico, 1964). But in acceding to American rule, Puerto Rico (unlike the NMI) did not seek further exemption from the Constitution's guarantees of individual rights. See generally Constitution of the Commonwealth of Puerto Rico, reprinted in id at 168 .

${ }^{132}$ None of the territories has full and effective voting representation in the United States Congress, nor do their residents vote in presidential elections.

${ }^{133}$ The federal government could accomplish this goal in at least three different ways: (1) by admitting territories as states; (2) by granting territories independence; or (3) by ceasing to govern the territories via its plenary powers under the Territorial Clause. Instead, Congress could enter into compacts with every territorial political community, and accord these agreements a legal status analogous to treaties concluded with Indian tribes, which are recognized as "treaties" within the meaning of the Constitution. See Worcester v Georgia, 31 US 515, 559 (1832).

134 I allude here to William Shakespeare, The Tragedy of Julius Caesar I, ii, 138-40. Men at some time are masters of their fates:

The fault, dear Brutus, is not in our stars,

But in ourselves, that we are underlings. 